\title{
AKTIVITAS ENZIM SELULASE MIKROBA YANG DIISOLASI DARI JERAMI PADI DI PERSAWAHAN PASANG SURUT DI KALIMANTAN SELATAN
}

\section{Enzyme Cellulase Activity Produced by Microbes Isolated from Rice Straw Grown on Tidal Swamp Rice Field South Kalimantan}

\author{
Fakhrur Razie1)*, Anas Iswandi2), Atang Sutandi2), Lukman Gunarto'), dan \\ Sugiyanta4)
}

\author{
1) Jurusan Tanah, Fakultas Pertanian, Universitas Lambung Mangkurat, Banjarbaru, Kalimantan Selatan 70123 \\ 2) Departemen Ilmu Tanah dan Sumberdaya Lahan, Fakultas Pertanian IPB, J1. Meranti Kampus IPB Darmaga \\ Bogor 16680 \\ 3) Balai Besar Penelitian Bioteknologi dan Sumberdaya Genetik Pertanian, J1. Tentara Pelajar No. 3A Kampus \\ Penelitian Pertanian Cimanggu Bogor 16111 \\ 4) Departemen Agronomi dan Hortikultura, Fakultas Pertanian IPB, J1. Meranti Kampus IPB Darmaga Bogor 16680
}

\begin{abstract}
Cellulase enzyme consists of three extracellular enzymes that work synergistically to degrade cellulose, namely endoglucanase, exoglucanase and $\beta$-glucosidase. These enzymes play a role in transforming insoluble polymers into soluble glucose. The aim of this researh were to isolate and purify cellulolytic microbes from tidal rice fields of South Kalimantan and know cellulolytic enzyme activity based on typology of tidal land. Ability of microbes to excrete endoglucanase enzymes based on cellulolytic index value in CMC media and the ability of microbes to excrete exoglucanase and $\beta$-glucosidase enzymes were measured using a modified method of Mandel. The results showed that the range of index values of microbial cellulolytic isolated from type A in tidal rice fields was 2.29-3.72, isolated from type $B$ was 2.66-5.41, and isolated from type $C$ was 1.843.34. Exoglucanase activity of cellulolytic microbial isolated from type A in tidal rice fields was $0.27-1.65 \mathrm{nkat} \mathrm{mL}^{-1}$, isolated from type $B$ was $0.371 .85 \mathrm{nkat} \mathrm{mL}^{-1}$, and isolated from type $C$ ranged between 0.31 and $1.85 \mathrm{nkat} \mathrm{mL}^{-1}$. Cellulolytic microbial were isolated from tidal rice fields of South Kalimantan had activity of $\beta$-glucosidase between 0.05 and $1.52 \mathrm{nkat}^{\mathrm{m} L^{-1}}$. Ultimately, Cellulolytic microbial isolates that have the highest cellulase activity were the cellulolytic bacterial isolates of J11, J42, R23, BK12, C52, TB41, B82 and SN123, and cellulolytic fungi isolates of ST33, ST22, TB31, B52, GA22, TD11, PI52 and P31.
\end{abstract}

Keywords: Cellulase, cellulolytic bacteria, cellulolytic fungi, tidal rice fields

\section{ABSTRAK}

Enzim selulase terdiri dari tiga enzim ekstraselular yang bekerja secara sinergis dalam mendegredasi selulosa, yakni endoglukanase, eksoglukanase dan $\beta$-glukosidase. Tiga enzim tersebut berperan dalam mendegradasi selulosa menjadi gula sederhana. Penelitian ini bertujuan untuk mengisolasi dan menyeleksi mikroba (bakteri dan fungi) berdasarkan aktivitas enzim selulase dari mikroba tanah yang diisolasi dari persawahan pasang surut Kalimantan Selatan. Kemampuan mengekskresikan enzim endoglukanase dinilai berdasarkan nilai indeks selulolitik pada media CMC dan kemampuan mengekskresikan enzim eksoglukanase dan $\beta$-glukosidase diukur dari aktivitas kedua enzim tersebut menggunakan metode Mandel yang dimodifikasi. Hasil yang diperoleh menunjukkan bahwa kisaran nilai indeks selulolitik dari mikroba selulolitik di persawahan pasang surut tipe A sebesar 2.29-3.72, di lahan tipe B sebesar 2.66-5.41, dan di lahan tipe C sebesar 1.84-3.34. Aktivitas eksoglukanase dari mikroba selulolitik di persawahan pasang surut tipe A sebesar 0.27-1.65 nkat $\mathrm{mL}^{-1}$, lahan tipe B sebesar 0.37-1.85 nkat mL ${ }^{-1}$, dan lahan tipe $C$ sebesar 0.31-1.85 nkat $\mathrm{mL}^{-1}$. Mikroba selulolitik dari persawahan pasang surut Kalimantan Selatan memiliki aktivitas $\beta$-glukosidase sebesar 0.05-1.52 nkat $\mathrm{mL}^{-1}$. Isolat- isolat mikroba selulolitik yang memiliki aktivitas selulase tertinggi adalah isolat bakteri selulolitik J11, J42, R23, BK12, C52, TB41, B82 dan SN123, dan isolat fungi selulolitik ST33, ST22, TB31, B52, GA22, TD11, PI52 dan P31.

Kata kunci: Selulase, bakteri selulolitik, fungi selulolitik, persawahan pasang surut

\section{PENDAHULUAN}

Pengomposan jerami padi secara alami di persawahan pasang surut Kalimantan membutuhkan waktu 2-3 bulan. Sisa jerami padi ditebas dan dibiarkan terhampar selama 1-1.5 bulan, saat mulai membusuk dikumpulkan dan dibentuk seperti bola (dipuntal) berdiameter 40-50 cm dan membusuk kira-kira 2 minggu. Setelah itu dibalik dan dibiarkan kira-kira 2 minggu untuk selanjutnya dihamparkan dan bagian jerami yang belum

*Penulis Korespondensi: Telp. +6281348343793; Email.fakhrurrazie@yahoo.com 
terlapuk dipotong-potong atau dikumpulkan membentuk galangan. Proses ini dikenal dengan sistem tepulikampar, yaitu dengan cara ditebas, dipuntal, dibalik dan diampar (Warta Penelitian dan Pengembangan Pertanian, 2007).

Proses pengomposan jerami padi yang lama disebabkan jerami mengandung senyawa-senyawa sukar lapuk, yaitu 35-45\% selulosa, 18-25\% hemiselulosa dan 10-25\% lignin (Galletti dan Antonetti, 2011; Lynd et al., 2002). Chew et al. (2001) menunjukkan bahwa degredasi bahan kapas (mengandung 96\% selulosa) mencapai 75\% setelah 25 hari dimasukkan tanah yang subur dan mencapai 18.4-41.9\% pada tanah yang terkontaminasi logam-logam berat. Pengomposan bahan jerami membutuhkan teknologi yang mampu mempercepat degradasi selulosa.

Selulosa adalah polimer glukosa rantai lurus dengan ikatan $\beta-1.4$ glukosida dari suatu selobiosa yaitu dimer dari glukosa (Shuangqi et al., 2011). Rantai lurus tersebut berhubungan melalui ikatan hidrogen dan gaya van der Waals (Perez et al., 2002). Selulosa mengandung sekitar 50-90\% bagian berkristal dan sisanya bagian amorf. Ikatan $\beta-1.4$ glukosida pada serat selulosa dapat dipecah menjadi monomer glukosa dengan cara hidrolisis asam atau enzimatis.

Selulosa dapat didegradasi oleh enzim selulase yang dapat dihasilkan oleh mikroba. Enzim tersebut mendegradasi molekul selulosa yang tidak larut menjadi mono atau disakarida sederhana larut sehingga dapat digunakan oleh mikroba sebagai sumber energi. Degradasi selulosa merupakan hasil kerja tiga komponen enzim secara sinergis, yaitu endoglukanase, eksoglukanase, dan $\beta$-glukosidase (Lymar et al., 1995). Beberapa mikroba yang berperan dalam proses dekomposisi seperti Achromo bacteria, Bacillus, Cellulomonas, Clostridium, Cytophaga, Vibrio Pseudomonas, dan Sporocytophaga merupakan kelompok bakteri selulolitik, dan Aspergillus, Chaetomium, Fusarium, Pencillium, Rhizoctonia, Rhizopus dan Trichoderma merupakan kelompok fungi selulolitik.

Persawahan di daerah pasang surut dipengaruhi intrusi dan endapan dari laut atau sungai yang bercampur dengan bahan endapan dari hulu lebih tinggi, menjadikan daerah ini memiliki kekhasan, yakni adanya usur-unsur logam yang dapat meracuni tanaman (Fe dan $\mathrm{Al}$ ), rendahnya kesuburan tanah, adanya pasang surut air dan adanya akumulasi bahan organik dari bahan jerami akan mempengaruhi keberadaan mikroba selulolitik dan kemampuannya dalam mendekomposisikan bahan organik. Tujuan penelitian adalah mengisolasi dan menyeleksi mikroba selulolitik berdasarkan kemampuannya menghasilkan enzim selulase.

\section{BAHAN DAN METODE}

Penelitian dilaksanakan di Laboratorium Bioteknologi Tanah Departemen Ilmu Tanah dan Sumberdaya Lahan Fakultas Pertanian Institut Pertanian Bogor dan di Laboratorium Mikrobiologi Fakultas Matematika dan Ilmu Pengetahuan Alam Universitas Lambung Mangkurat.

\section{Bahan dan Alat}

Kompos jerami yang sedang melapuk sebagai sumber isolat diambil dari persawahan pasang surut di Kalimantan Selatan, yaitu di Kabupaten Barito Kuala (desa Barambai, Beringin Kencana, Cerbon, Gambah Asahi, Jelapat, Koanda, Marabahan, Purwosari I, Rumpiang, Simpang Nungki, Sungai Bamban) dan di Kabupaten Banjar (desa Penggalaman, Sungai Rangas dan Sungai tabuk). Kompos jerami tersebut umumnya berasal dari jerami padi varitas lokal, yaitu varietas Siam Unus dan Siam Pandak. Media yang dipergunakan pada penelitian ini adalah Medium Pengayaan (Enrichment culture medium) dengan komposisi $\mathrm{KH}_{2} \mathrm{PO}_{4} 1 \mathrm{~g} \mathrm{~L}^{-1},\left(\mathrm{NH}_{4}\right)_{2} \mathrm{SO}_{4} 1$ $\mathrm{g} \mathrm{L}^{-1}, \mathrm{NaCl} 1 \mathrm{~g} \mathrm{~L}^{-1}, \mathrm{MgSO}_{4} .7 \mathrm{H}_{2} \mathrm{O} 2.4 \mathrm{~g} \mathrm{~L}^{-1}, \mathrm{CaCl}_{2} 0.1 \mathrm{~g} \mathrm{~L}^{-}$ ${ }^{1}$ dan substrat serbuk jerami (sebagai sumber C) $100 \mathrm{~g} \mathrm{~L}^{-1}$ dan $\mathrm{pH}$ media ditetapkan dengan $\mathrm{NaOH} 0.01 \mathrm{M}$ hingga $\mathrm{pH}$ 7, serta medium mengandung selulosa dengan komposisi Carboxy Methyl Cellulose (CMC) $10 \mathrm{~g} \mathrm{~L}^{-1}, \mathrm{KH}_{2} \mathrm{PO}_{4} 1 \mathrm{~g} \mathrm{~L}$ ${ }^{1}, \mathrm{~K}_{2} \mathrm{SO}_{4} 0.5 \mathrm{~g} \mathrm{~L}^{-1}$, NaCl $0.5 \mathrm{~g} \mathrm{~L}^{-1}, \mathrm{FeSO}_{4} 0.01 \mathrm{~g} \mathrm{~L}^{-1}$, $\mathrm{MnSO}_{4} 0.01 \mathrm{~g} \mathrm{~L}^{-1}, \mathrm{NH}_{4} \mathrm{NO}_{3} 1 \mathrm{~g} \mathrm{~L}^{-1}, \mathrm{MgSO}_{4} 0.2 \mathrm{~g} \mathrm{~L}^{-1} \mathrm{dan}$ Agar $20 \mathrm{~g} \mathrm{~L}^{-1}$ (Susilowati et al., 2003).

\section{Metode}

Sumber isolat bahan jerami yang terdekomposisi alami diambil dari persawahan pasang surut di wilayah Kabupaten Barito Kuala dan Banjar Kalimantan Selatan. Sumber isolat dimasukkan ke dalam kantong plastik steril dan disimpan dalam termos es saat di lapangan dan selanjutnya disimpan dalam lemari pendingin sebelum dilakukan kegiatan isolasi dan pemurnian bakteri dan jamur selulolitik.

\section{Isolasi dan Pemurnian Mikroba Selulolitik}

Sumber isolat yang belum terdekomposisi secara sempurna dipotong-potong $( \pm 2-5 \mathrm{~cm})$ masing-masing sebanyak $10 \mathrm{~g}$ disuspensikan ke dalam $90 \mathrm{~mL}$ medium pengayaan. Suspensi tersebut digoyang di atas shaker berkecepatan $100 \mathrm{rpm}$ pada suhu ruang selama 3 hari. Selanjutnya $10 \mathrm{~mL}$ suspensi diambil dan dimasukkan ke dalam $90 \mathrm{~mL}$ medium mineral yang telah ditambah substrat serbuk jerami dan digoyang di atas shaker lagi. Setelah itu, $10 \mathrm{~mL}$ suspensi yang baru dimasukan ke dalam $90 \mathrm{~mL}$ medium mineral, ditambah substrat serbuk gergaji dan kembali digoyang. Kemudian $0.1 \mathrm{~mL}$ suspensi hasil biakan disebar pada cawan petri berisi medium CMC (Carboxy Methyl Cellulose) padat.

Pertumbuhan dan kemampuan bakteri merombak bahan organik ditandai dengan terbentuknya zona bening pada medium CMC. Zona bening yang timbul menunjukkan terjadinya hidrolisis bahan organik dalam substrat yang diakibatkan oleh enzim selulase dari mikroba. Isolat-isolat yang diperoleh dimurnikan, diperbanyak dan disimpan pada lemari pendingin yang suhunya berkisar $4{ }^{0} \mathrm{C}$ menggunakan media agar miring CMC. Dalam mengisolasi dipisahkan antara bakteri dan jamur. Selanjutnya dilakukan pengujian isolat perombak bahan organik berdasarkan kemampuannya 1) mengekskresikan enzim selulase, 2) ketahanan terhadap kondisi lingkungan tanah (berdasarkan kemasaman tanah) yang diberi bahan organik, dan 3) mempercepat proses pengomposan. 


\section{Penetapan Aktivitas Endoglukanase}

Isolat yang telah dimurnikan ditumbuhkan pada cawan petri dengan menggunakan media CMC, selanjutnya diinkubasi selama 4 hari pada suhu $27{ }^{0} \mathrm{C}$ dalam inkubator. Pada akhir inkubasi diukur diameter koloninya, kemudian inkubasi dilanjutkan hingga berumur satu minggu dan dilakukan pewarnaan dengan congo red pada kedua media tersebut. Selanjutnya dilakukan pengukuran diameter koloni dan diameter zona bening. Kemampuan mengeksresikan selulase dihitung dari nisbah antara diameter zona bening dibagi diameter koloni. Pengukuran setiap isolat akan diulang sebanyak 4 kali.

\section{Penetapan Aktivitas Eksoglukanase dan $\beta$-glukosidase}

Enzim selulase diperoleh dengan cara pembuatan starter dari mikroba selulolitik seperti dijelaskan oleh Susilowati et al. (2003) yaitu menumbuhkan isolat tersebut dalam $150 \mathrm{~mL}$ media produksi Mandels $\left(14 \%\left(\mathrm{NH}_{4}\right)_{2} \mathrm{SO}_{4}\right.$, $20 \% \mathrm{KH}_{2} \mathrm{PO}_{4}, 3 \% \mathrm{MgSO}_{4} .7 \mathrm{H}_{2} \mathrm{O}$, 3\% Urea, 30\% $\mathrm{CaCl}_{2}$, $0.5 \% \mathrm{FeSO}_{4}, 1.6 \% \mathrm{MnSO}_{4}, 1.4 \% \mathrm{ZnSO}_{4}$, dan $2 \% \mathrm{CoCl}_{2}$ ) yang dimodifikasi dengan penambahan serbuk jerami sebagai sumber karbonnya, selanjutnya diinkubasi pada suhu kamar selama 5 x 24 jam dengan digoyang pada shaker berkecepatan $150 \mathrm{rpm}$. Enzim selulase kasar dipanen dengan cara mensentrifuse dengan kecepatan 15,000 rpm pada suhu $4{ }^{0} \mathrm{C}$ selama 15 menit dan supernatannya diambil. Selanjutnya pengukuran aktivitas selulase dilakukan dengan cara berikut: aktivitas enzim eksoglukanase digunakan $1 \mathrm{~mL}$ filtrat enzim, $1 \mathrm{~mL}$ bufer fosfat $\mathrm{pH}$ 7.00, 1\% substrat mikrokristalin (Avicel) dan aktivitas enzim $\beta$-glukosidase digunakan kertas saring Whatman No.1. Pra-inkubasi campuran filtrat enzim, buffer fosfat, dan substrat dilakukan dalam tabung berisi air di atas penangas api selama 5 menit, lalu divortik masing-masing campuran. Inkubasi pada pengujian aktivitas $\beta$-glukosidase dilakukan selama 30 menit pada suhu $45{ }^{0} \mathrm{C}$, sedangkan pada pengujian aktivitas eksoglukanase selama 1 jam pada suhu $60{ }^{\circ} \mathrm{C}$. Setelah itu, dilakukan penambahan $3 \mathrm{~mL}$ larutan DNS (Dinitro Salicylic Acid), divorteks, dan dimasukkan ke dalam air mendidih selama 15 menit. Kontrol disiapkan dengan menambahkan $1 \mathrm{~mL}$ filtrat enzim setelah penambahan 3 $\mathrm{mL}$ DNS, sedangkan blanko berisi campuran $2 \mathrm{~mL}$ akuades, $1 \mathrm{~mL}$ bufer, dan $3 \mathrm{~mL}$ DNS. Selanjutnya dilakukan pembacaan absorbansi pada panjang gelombang $540 \mathrm{~nm}$. Satu unit aktivitas enzim ialah banyaknya enzim yang dapat memproduksi $1 \mu$ mol glukosa dalam 1 menit pada kondisi pengukuran enzim. Satu unit aktivitas setara dengan 16.7 nkat (Dybkaer, 2001).

\section{Metode Seleksi Isolat}

Penentuan isolat-isolat selulolitik terseleksi pada setiap pengujian dilakukan dengan cara skoring dari tiap peubah yang diukur. Data hasil pengukuran indeks selulolitik, enzim eksoglukanase dan $\beta$-glukosidase pada setiap ulangan pengukuran diurut dari yang terendah hingga tertinggi dan diberi nilai skor mulai dari 1 untuk nilai terendah hingga n untuk nilai tertinggi sesuai jumlah isolat yang diuji. Nilai skor dari ulangan setiap isolat dijumlahkan untuk mendapatkan skor akhir dari isolat tersebut. Seleksi berdasarkan kemampuan dalam mengekskresikan enzim endoglukanase tidak dibedakan antara isolat bakteri dan fungi selulolitik. Pada seleksi awal ini selain isolat yang memiliki total nilai skor tinggi (20 isolat), juga diseleksi yang memiliki total nilai skor sedang dan rendah (masing-masing 10 isolat) sebagai pembanding untuk seleksi selanjutnya. Pada seleksi berdasarkan aktivitas enzim eksoglukanase dan $\beta$ glukosidasenya dipilih isolat bakteri dan fungi selulolitik yang memiliki total nilai skor tinggi (masing-masing delapan isolat) dan dua isolat bakteri dan fungi selulolitik yang memiliki total nilai rendah sebagai pembanding untuk seleksi selanjutnya, sehingga ada 20 isolat selulolitik yang terseleksi.

\section{Analisis Data}

Hasil pengukuran indeks selulolitik dan aktivitas enzim eksoglukanase dan $\beta$-glukosidase dilakukan analisis ragam untuk mengetahui pengaruh perbedaan dari isolatisolat tersebut berdasarkan lokasi pengambilan sampel. Jika menunjukan pengaruhnya dilakukan uji beda nilai tengah untuk mengetahui perbedaan antar lokasi pengambilan sampel.

\section{HASIL DAN PEMBAHASAN}

\section{Isolasi dan Pemurnian Mikroba Selulolitik}

Seratus sumber isolat yang dikoleksi dari persawahan pasang surut di Kabupaten Barito Kuala dan Banjar Kalimantan Selatan diisolasi sebanyak 3 kali ulangan dan diperoleh sebanyak 143 isolat selulolitik murni. Rekapitulasi daftar sumber isolat dan isolat mikroba selulolitik yang diperoleh berdasarkan lokasi dan tipologi lahan pasang surut isolat tersebut disajikan pada Tabel 1.

Lahan pasang surut terdiri dari 4 tipe lahan, yaitu lahan tipe A adalah lahan yang terluapi pada pasang besar maupun pasang kecil, tipe $\mathrm{B}$ adalah lahan yang hanya terluapi ketika pasang besar, tipe $\mathrm{C}$ adalah lahan yang tidak terluapi pada pasang besar dan kecil, dan kedalaman air tanah kurang dari $50 \mathrm{~cm}$, dan tipe D adalah lahan yang tidak terluapi pada pasang besar maupun kecil dan kedalaman muka air tanah lebih dari $50 \mathrm{~cm}$ (Widjaja-Adhi et al., 1997). Isolasi dan pemurnian mikroba selulolitik dari 45 sumber isolat dari lahan tipe A diperoleh 43 isolat fungi dan 25 isolat bakteri selulolitik, dari 42 sumber isolat yang dikoleksi dari lahan tipe B diperoleh sebanyak 28 isolat fungi dan 31 isolat bakteri selulolitik, dan dari 13 sumber isolat yang dikoleksi dari lahan tipe $\mathrm{C}$ diperoleh 4 isolat fungi dan 12 isolat bakteri selulolitik. Jumlah isolat fungi selulolitik yang ditemukan dari semua lokasi sumber isolat lahan tipe A lebih banyak dibandingkan dengan bakteri selulolitik. Kondisi lahan tipe A yang selalu terluapi sehingga kekurangan oksigen. Hal tersebut lebih membatasi keberadaan bakteri selulolitik jika dibandingkan dengan fungi selulolitik. Sebaliknya pada lahan tipe $\mathrm{C}$ dengan kondisi lingkungan yang lebih aerob jika dibandingkan dengan tipe $\mathrm{A}$, ditemukan bakteri selulolitik pada semua lokasi sumber isolat di lahan tipe C lebih tinggi dibandingkan dengan fungi selulolitik. Singh et al. (2010) menjelaskan bahwa keberadaan mikrob selulolitik dalam tanah berhubungan dengan sistem pengelolaan lahan yang berhubungan dengan pengaruh 
kondisi lingkungan terhadap kelimpahan dan aktivitas dekomposisinya.

Tabel 1. Sumber isolat dan mikroba selulolitik yang diperoleh dari persawahan pasang surut Kalimantan Selatan

\begin{tabular}{|c|c|c|c|c|c|}
\hline \multirow[t]{2}{*}{ No } & \multirow[t]{2}{*}{ Lokasi (tipologi lahan) } & \multirow{2}{*}{$\begin{array}{c}\text { Lokasi } \\
\text { Sumber } \\
\text { Isolat }\end{array}$} & \multicolumn{3}{|c|}{$\begin{array}{c}\text { Jumlah isolat yang } \\
\text { dimurnikan }\end{array}$} \\
\hline & & & Fungi & Bakteri & Total \\
\hline 1. & Berambai (tipe B) & 8 & 8 & 3 & 11 \\
\hline 2. & Beringin Kencana (tipe A) & 5 & 4 & 1 & 5 \\
\hline 3. & Cerbon (tipe B) & 5 & 3 & 6 & 9 \\
\hline 4. & Gambah Asahi (tipe B) & 5 & 1 & 9 & 10 \\
\hline 5. & Jelapat (tipe A) & 5 & 7 & 0 & 7 \\
\hline 6. & Koanda (tipe A) & 10 & 9 & 0 & 9 \\
\hline 7. & Marabahan (tipe B) & 8 & 0 & 14 & 14 \\
\hline 8. & Penggalaman (tipe B) & 4 & 3 & 1 & 4 \\
\hline 9. & Purwosari I (tipe A) & 5 & 5 & 1 & 6 \\
\hline 10. & Rumpiang (tipe A) & 4 & 7 & 1 & 8 \\
\hline & Simpang Nungki (tipe A) & 12 & 14 & 3 & 17 \\
\hline 12. & Sungai Bamban (tipe B) & 5 & 1 & 5 & 6 \\
\hline & Sungai Rangas (tipe C) & 9 & 4 & 5 & 9 \\
\hline 14. & Sungai Tabuk (tipe C) & 4 & 0 & 7 & 7 \\
\hline 15. & $\begin{array}{l}\text { Tinggiran Baru mekarsari } \\
\text { (tipe A) }\end{array}$ & 9 & 14 & 3 & 17 \\
\hline 16. & Tinggiran Dalam (tipe B) & 5 & 3 & 1 & 4 \\
\hline \multicolumn{6}{|c|}{ Tipologi lahan pasang surut* } \\
\hline & tipe A & 45 & 43 & 25 & 68 \\
\hline 2. & tipe B & 42 & 28 & 31 & 59 \\
\hline & tipe C & 13 & 4 & 13 & 16 \\
\hline & Jumlah & 100 & 83 & 60 & 143 \\
\hline
\end{tabular}

Keterangan: * Isolasi setiap sumber isolat dilakukan 3 kali

Tipe D tidak ditemukan sumber isolat dari jerami hasil panen sebelumnya saat penelitian

Pada lahan tipe B, isolat bakteri selulolitik pada lokasi Cerbon, Gambah Asahi, Marabahan dan Sungai Bamban lebih banyak ditemukan dibanding fungi selulolitik, tetapi isolat bakteri selulolitik pada lokasi Beringin Kencana, Penggalaman dan Tinggiran baru lebih sedikit ditemukan dibandingkan fungi selulolitik. Lahan pasang surut tipe B yang terluapi ketika pasang besar dan tidak terluapi ketika pasang kecil pada beberapa bulan atau periodik pasang surut air dalam satu bulan menimbulkan perubahan kondisi aerob dan anaerob sehingga sebagian dari lokasi sumber isolat di lahan tipe B lebih banyak bakteri selulolitik dibanding dengan fungi selulolitik dan sebaliknya.

\section{Kemampuan Mengekskresikan Endoglukanase}

Kemampuan isolat-isolat selulolitik dari persawahan pasang surut Kalimantan Selatan (sebanyak 143 isolat) dalam mengekskresikan enzim endoglukanase didasarkan pada nilai indeks selulolitik pada media CMC. Nilai indeks selulolitik menggambarkan kemampuan isolat-isolat mikroba selulolitik dalam mengekskresikan enzim endoglukanase (CMC-ase), semakin besar nilai indeks selulolitik maka semakin besar kemampuan dalam mengekskresikan CMC-ase. Sirisena dan Manamendra (1995) menjelaskan bahwa salah satu enzim yang dibutuhkan untuk merubah selulosa menjadi glukosa adalah endo-1.4 $\beta$-glukonase yang dapat dideteksi dengan hidrolisis CMC dari nilai indeks selulolitik. Endoglukanase merupakan komponen selulase yang selalu ditemukan pada mikroorganisme selulolitik.
Enzim ini memiliki afinitas yang tinggi terhadap turunan selulosa dan bereaksi secara acak pada serat selulosa yang amorf, aktivitas yang tinggi pada substrat CMC dan menyebabkan penurunan viskositas substrat yang dapat larut (Ilmen et al., 1997). Kemampuan isolatisolat dalam mengekskresikan selulase yang diukur dari nilai indeks selulolitiknya berdasarkan lokasi sumber isolat dapat dilihat pada Gambar 1. Mikroba selulolitik yang dikoleksi dari persawahan pasang surut Kalimantan Selatan yang memiliki endoglukanase (nilai indeks selulolitik) tinggi ditemukan di lahan tipe B Berambai yaitu 5.41. Sedangkan yang terendah ditemukan di lahan tipe C Sungai Tabuk yaitu 1.84. Kisaran nilai indeks selulolitik di persawahan pasang surut tipe A berkisar antara 2.29 dan 3.72; lahan tipe B berkisar antara 2.66 dan 5.41, dan pada lahan tipe C berkisar antara 1.84 dan 3.34. Namun demikian dari kisaran nilai indeks selulolitik tersebut hanya pada lahan tipe $B$ yang memiliki nilai indeks yang meningkat secara nyata. Hal ini diduga disebabkan variabilitas lahan tipe B lebih besar dibanding tipe lainnya, terutama disebabkan oleh kondisi aerob dan anaerob di lahan ini.

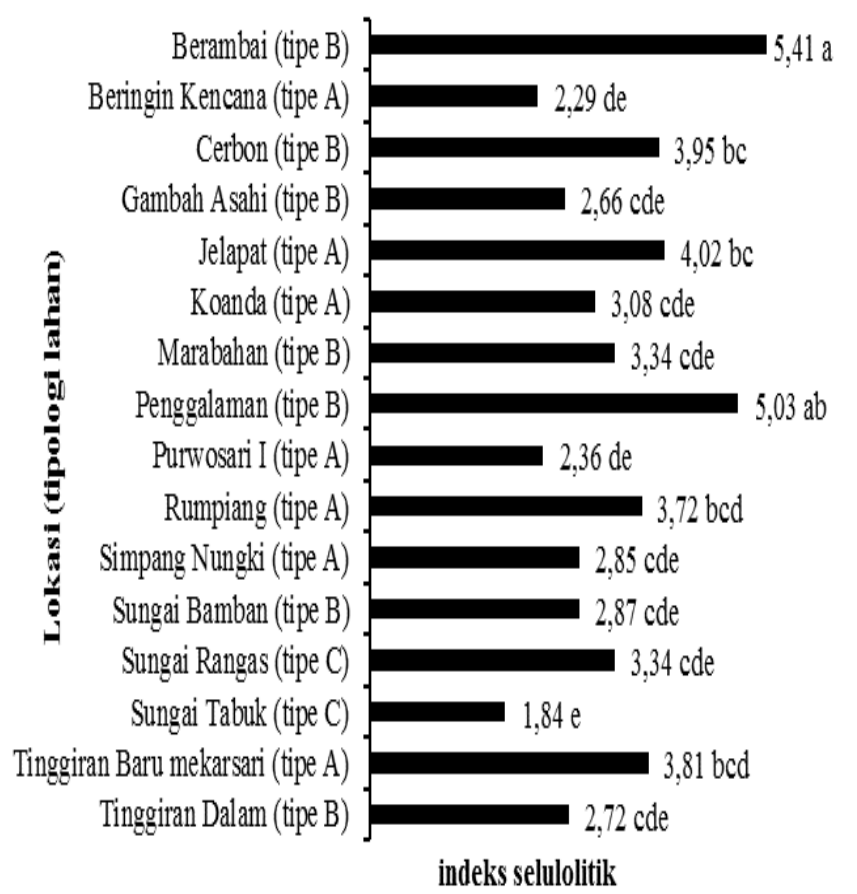

Keterangan: Koefisien Keragaman $=6.11 \%$. angka yang diikuti huruf yang sama tidak menunjukkan perbedaan menurut uji Duncan pada taraf nyata 5\%, A, B dan C = tipologi lahan

Gambar 1. Nilai Indeks selulolitik dari isolat-isolat yang dimurnikan berdasarkan lokasi sumber isolat diperoleh

\section{Seleksi Isolat Berdasarkan Nilai Indeks Selulolitik}

Dua puluh isolat yang memiliki total nilai skor tinggi dari nilai indeks selulolitiknya yaitu 342-439, dan masing-masing 10 isolat yang memiliki total nilai skor sedang dan rendah dari nilai indeks selulolitik masingmasing 219-221 dan 4-38 (Tabel 2). 
Tabel 2. Mikrob selulolitik sebanyak 40 isolat mikroba selulolitik yang digunakan untuk menilai indeks selulolitik berdasarkan lokasi (tipologi lahan)

\begin{tabular}{|c|c|c|c|c|}
\hline \multirow{2}{*}{ No } & \multirow{2}{*}{ Lokasi (tipologi lahan) } & \multicolumn{3}{|c|}{ Isolat mikroba dengan nilai indeks seluloltik } \\
\hline & & Tinggi & Sedang & Rendah \\
\hline 1. & Berambai (tipe B) & B22, B51, B82, B52 & - & - \\
\hline 2. & Beringin Kencana (tipe A) & - & BK12 & BK31 \\
\hline 3. & Cerbon (tipe B) & C32, C52 & - & - \\
\hline 4. & Gambah Asahi (tipe B) & GA22 & GA21 & - \\
\hline 5. & Jelapat (tipe A) & J43 & J11, J42 & - \\
\hline 6. & Koanda (tipe Á) & - & K42 & - \\
\hline 7. & Marabahan (tipe B) & M33, M51, M72 & M53, M212 & M512, M711 \\
\hline 8. & Penggalaman (tipe B) & P31 & - & - \\
\hline 9. & Purwosari I (tipe A) & - & - & PI52 \\
\hline 10. & Rumpiang (tipe A) & R11, R23 & - & - \\
\hline 11. & Simpang Nungki (tipe A) & SN21 & - & SN123 \\
\hline 12. & Sungai Bamban (tipe B) & SB12 & SB41 & - \\
\hline 13. & Sungai Rangas (tipe C) & SR12 & SR41 & - \\
\hline 14. & Sungai Tabuk (tipe C) & - & ST21 & ST22, ST33 \\
\hline 15. & Tinggiran Baru mekarsari (tipe A) & TB52, TB32, TB42 & TB103, TB31, TB41 & \\
\hline 16. & Tinggiran Dalam (tipe B) & - & - & TD11 \\
\hline
\end{tabular}

\section{Seleksi Isolat Berdasarkan Aktivitas Eksoglukanase dan $\beta$-glukosidase}

Berdasarkan aktivitas isolat dalam menghasilkan enzim eksoglukanase dan $\beta$-glukosidase diperoleh 20 isolat terseleksi yaitu 8 isolat bakteri dan 8 isolat fungi selulolitk yang memiliki total nilai skor tertinggi sebesar 76-110 dan 68-101 dan dua isolat bakteri dan dua isolat fungi memiliki total nilai skor terendah (45-52 dan 10-13). Delapan isolat bakteri selulolitik yang memiliki total nilai skor tinggi adalah J11, J42, R23, BK12, C52, TB41, B82 dan SN123, sedangkan delapan isolat fungi selulolitik yang memiliki total nilai skor tertinggi adalah ST33, ST22, TB31, B52, GA22, TD11, PI52 dan P31. Selanjutnya dua isolat bakteri selulolitik yang memiliki total nilai skor rendah adalah TB103 dan SN21, dan dua isolat fungi yang memiliki total nilai skor rendah adalah M72 dan GA31.

\section{Kemampuan Mengekskresikan Eksoglukanase dan $\beta$ - glukosidase}

Aktivitas eksoglukanase dan $\beta$-glukosidase dari 40 isolat terseleksi berdasarkan lokasi sumber isolat dapat dilihat pada Tabel 3. Aktivitas eksoglukanase tertinggi ditemukan di Tinggiran Dalam (1.85 nkat $\mathrm{mL}^{-1}$ ) diikuti oleh sumber isolat Rumpiang dan Jelapat masing-masing sebesar 1.65 dan 1.58 nkat $\mathrm{mL}^{-1}$, sedangkan aktivitas eksoglukanase terendah ditemukan di lahan tipe A simpang Nungki sebesar 0.27 nkat $\mathrm{mL}^{-1}$.

Aktivitas enzim selulase pada substrat Avicel memotong ujung substrat selulosa yang berbentuk kristalin, menunjukkan adanya aktivitas enzim ekso-1,4- $\beta$ glukanase atau selobiohidrolase, dimana ujung rantai oligo-sakarida menjadi selobiosa, yaitu dua molekul glukosa yang berikatan secara $\beta$-1,4-glikosidik (Meryandini et al. 2009). Pemutusan $\beta$-1,4-glikosida dari dua molekul glukosa dilakukan oleh enzim glukosidase menjadi gula-gula reduksi sederhana. Aktivitas enzim eksoglukanase di persawahan pasang surut tipe A berkisar antara 0.27 dan 1.65 nkat $\mathrm{mL}^{-1}$; lahan tipe B berkisar antara 0.37 dan 1.85 nkat $\mathrm{mL}^{-1}$; dan lahan tipe $\mathrm{C}$ berkisar antara 0.31 dan 1.85 nkat $\mathrm{mL}^{-1}$. Namun demikian nilai aktivitas isolat-isolat tersebut relatif lebih tinggi dibanding dengan aktivitas enzim dari bakteri selulolitik yang isolasi dari lahan pertanian di Jawab Barat, yaitu isolat bakteri selulolitik C4-4, C5-1 dan C 11-1 yakni 0.02-0.03 nkat $\mathrm{mL}^{-1}$ (Nur, 2007). Aktivitas enzim eksoglukanase mikroba selulolitik di lahan tipe A dan B secara nyata mengalami peningkatan dari aktivitas yang terendah hingga tertinggi.

Tabel 3. Aktivitas enzim eksoglukanase dan gluloksidase dari 40 isolat selulolitik terseleksi berdasarkan lokasi sumber isolat

\begin{tabular}{|c|c|c|c|}
\hline Isolat & Sumber Isolat & Eksoglukanase & $\beta$-glukosidase \\
\hline & & \multicolumn{2}{|c|}{----------- nkat $\mathrm{mL}^{-1}$---------- } \\
\hline B22, B51, B82, B52 & Berambai (tipe B) & $0.61 \mathrm{c}$ & $0.19 \mathrm{~b}$ \\
\hline BK12, BK31 & Beringin Kencana (tipe A) & $1.00 \mathrm{abc}$ & $0.13 \mathrm{~b}$ \\
\hline C32, C52 & Cerbon (tipe B) & $1.25 \mathrm{abc}$ & $0.20 \mathrm{~b}$ \\
\hline GA22, GA21 & Gambah Asahi (tipe B) & $0.47 \mathrm{c}$ & $0.16 \mathrm{~b}$ \\
\hline J43, J11, J42 & Jelapat (tipe A) & $1.58 \mathrm{ab}$ & $1.52 \mathrm{a}$ \\
\hline K42 & Koanda (tipe A) & $0.56 \mathrm{c}$ & $0.02 \mathrm{~b}$ \\
\hline M33, M51, M72, M53, M212, M512, M711 & Marabahan (tipe B) & $0.50 \mathrm{c}$ & $0.10 \mathrm{~b}$ \\
\hline P31 & Penggalaman (tipe B) & 0.75 abc & $0.06 \mathrm{~b}$ \\
\hline PI52 & Purwosari I (tipe A) & 0.52 c & $0.23 \mathrm{~b}$ \\
\hline R11, R23 & Rumpiang (tipe A) & $1.65 \mathrm{ab}$ & $0.32 \mathrm{~b}$ \\
\hline SN21, SN123 & Simpang Nungki (tipe A) & 0.27 c & $0.05 \mathrm{~b}$ \\
\hline SB12, SB41 & Sungai Bamban (tipe B) & 0.37 c & $0.09 \mathrm{~b}$ \\
\hline SR12, SR41 & Sungai Rangas (tipe C) & 0.31 c & $0.05 \mathrm{~b}$ \\
\hline ST21, ST22, ST33 & Sungai Tabuk (tipe C) & $1.10 \mathrm{bc}$ & $0.92 \mathrm{~b}$ \\
\hline ТВ52, ТВ32, ТВ42, ТВ103, ТВ31, ТВ41 & Tinggiran Baru mekarsari (tipe A) & $0.41 \mathrm{c}$ & $0.27 \mathrm{~b}$ \\
\hline \multirow[t]{2}{*}{ TD11 } & Tinggiran Dalam (tipe B) & $1.85 \mathrm{a}$ & $0.06 \mathrm{~b}$ \\
\hline & Koefisien keragaman (\%) & 2.09 & 1.79 \\
\hline
\end{tabular}

Keterangan: Angka-angka yang diikuti huruf yang sama pada masing-masing kolom menunjukkan tidak ada perbedaan dari lokasi menurut uji Duncan pada taraf nyata $5 \%$ 
Pada Tabel 3 dapat dilihat aktivitas enzim glukosidase. Enzim ini berperan dalam menghasilkan gula reduksi sederhana. Aktivitas $\beta$-glukosidase dari mikroba selulolitik dari persawahan pasang surut Kalimantan Selatan berkisar antara 0.02 dan 1.52 nkat $\mathrm{mL}^{-1}$. Aktivitas enzim $\beta$-glukosidase dari lahan tipe A Jelapat merupakan aktivitas enzim tertinggi 1.52 nkat $\mathrm{mL}^{-1}$. Dari penelitian Nur (2007) menunjukan bahwa aktivitas enzim $\beta$ glukosidase isolat bakteri selulolitik C4-4, C5-1 dan C 111 hanya berkisar 0.01-0.02 nkat $\mathrm{mL}^{-1}$, sedangkan aktivitas enzim $\beta$-glukosidase dari lokasi lainnya tidak menunjukkan perbedaan. Keadaan lahan yang tergenang di persawahan pasang surut tipe A dan adanya periodik penggenangan di tipe $\mathrm{B}$ dapat menjadikan kemasaman tanah akan turun. Sehingga beberapa mikroba selulolitik yang ditemukan di daerah ini mampu beraktivitas dengan baik ketika berada di lingkungan yang pHnya semakin naik.

\section{SIMPULAN}

1. Isolat yang diperoleh sebanyak 143 isolat, 43 fungi dan 25 bakteri berasal dari persawahan pasang surut tipe A; 28 fungi, 31 bakteri dari lahan tipe B; dan 4 fungi dan 12 bakteri dari lahan tipe $\mathrm{C}$.

2. Kisaran nilai indeks mikroba selulolitik di persawahan pasang surut tipe A sebesar 2.29-3.72, di lahan tipe B sebesar 2.66-5.41, dan di lahan tipe C sebesar 1.843.34. Aktivitas eksoglukanase dari lahan tipe A sebesar 0.27-1.65 nkat $\mathrm{mL}^{-1}$, lahan tipe B sebesar 0.37-1.85 nkat $\mathrm{mL}^{-1}$, dan lahan tipe C sebesar 0.31-1.85 nkat $\mathrm{mL}^{-}$ 1. Aktivitas $\beta$-glukosidase dari mikroba selulolitik sebesar 0.05-1.52 nkat $\mathrm{mL}^{-1}$.

3. Isolat bakteri selulolitik yang memiliki aktivitas selulase tertinggi adalah J11, J42, R23, BK12, C52, TB41, B82 dan SN123, dan isolat fungi selulolitik yang memiliki aktivitas selulase tertinggi adalah ST33, ST22, TB31, B52, GA22, TD11, PI52 dan P31.

\section{DAFTAR PUSTAKA}

Chew, I., J.P. Obbard, and R.R. Stanforth. 2001. Microbial cellulose decomposition in soils from a rifle range contaminate with heavy metals. Environ. Pollut., 111:367-375.

Dybkaer, R. 2001. Unit "katal” for catalytic activity. Pure Appl. Chem., 73:927-931.

Galletti, A.M.R. and C. Antonetti. 2011. Biomass pretreatment: separation of cellulose, hemicellulose and http://www.eurobioref.org/Summer_School /Lectures_Slides/day2/Lectures/L04_AG\%20Ras polli.pdf.

Ilmen, M.A., Saloheimo, O. Maija-Leena and M.E. Penttila. 1997. Regulation of Cellulase Gene Expression In The Filamentous Fungus Trichoderma Reesei. Appl. Environ. Microbiol., 63:1208-1306.
Lymar, E.S., B. Li and V. Renganathan. 1995. Purification and characterization of a cellulosebinding $\beta$ - glucosidase from cellulose degrading culture of Phanerochaete chrysosporium. Appl. Environ. Microbiol., 61:2976-2980.

Lynd, L.R., P.J. Weimer, W.H, van Zyl and I.I. Pretorius. 2002. Microbial cellulose utilization: fundamentals and biotechnology. Microbiol. Mol. Biol. Rev., 66:506-577.

Meryandini, A., W. Widosari, B. Maranatha, T.C. Sunarti, N. Rachmania dan H. Satria. 2009. Isolasi bakteri selulolitik dan karakterisasi enzimnya. Makara Sains, 13:33-38.

Nur, H.S. 2007. Aplikasi enzim bakteri selulolitik dan xilanolitik dalam dekomposisi substrat limbah tanaman padi [tesis]. Institut Pertanian Bogor.

Perez, J., J. Munoz-Dorado, T. de la Rubia and J. Martinez. 2002. Biodegradation and biological treatments of cellulose, hemicellulose and lignin: an overview. Int. Microbiol., 5:53-63.

Sirisena, D.M. and T.P. Manamendra. 1995. Isolation and characterization of cellulolytic bacteria from decomposing rice straw. J. Nat. Sci. Country, 23:25-30.

Singh, M., S. Khanna, and N.T. Prakash. 2010. Influence of Cellulolytic Bacterial Augmentation on organic and available phosphorus in sandy loam soil under cultivation. J. Agric. Sci., 2:137-145.

Susilowati, D.N., Rosmimik, R. Saraswati, R.D.M, Simanungkalit, dan L. Gunarto. 2003. Koleksi, karakterisasi, dan preservasi mikroba penyubur tanah dan perombak bahan organik dalam Prosiding Seminar Hasil Penelitian Rintisan dan Bioteknologi Tanaman, Bogor, 23-24 September 2003.

Shuangqi, T., W. Zhenyu, F. Ziluan, Z. Lili and W. Jichang. 2011. Determination methods of cellulase activity. Afr. J. Biotech., 10:7122-7125.

Warta Penelitian dan Pengembangan Pertanian. 2007. Konservasi Lahan Pasang Surut dengan Teknologi Tradisional "Tepulikampar”. Balai Penelitian Pertanian Lahan Rawa. Banjarbaru. hlm 10.

Widjaja-Adhi, I.P.G., N.P.S. Ratmini dan I,W. Swastika. 1997. Pengelolaan tanah dan air di lahan pasang surut. Proyek Penelitian Pengembangan Pertanian Rawa Terpadu-ISDP. Badan Penelitian dan Pengembangan Pertanian. Bogor. hlm 5. 
